\title{
РОЗРАХУНОК РИЗИКУ РОЗВИТКУ СЕРЦЕВО- СУДИННОї ПАТОЛОГІї, ЩО МАЕ ТРИВАЛИЙ ПЕРЕБІГ, У ПОСТРАЖДАЛОГО З БОЙОВОЮ ТРАВМОЮ: КЛІНІЧНИЙ ВИПАДОК
}

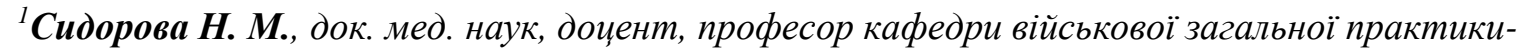
сімейної медицини;

${ }^{1}$ Пешкова М. І., клінічний ординатор кафедри військової терапії;

${ }^{l}$ Воронко А. А., канд. мед. наук, дочент, завідувач кафедри військової загальної практикисімейної медицини;

${ }^{2}$ Хоменко I. В., лікар-ординатор клініки загальної терапї;

${ }^{2}$ Третяк Д. Д., начальник клініки загальної терапї;

${ }^{1}$ Українська військово-медична академія, Украӥна, м. Київ;

${ }^{2}$ Начіональний військово-медичний клінічний центр «Головний військовий клінічний госпіталь», Украӥна, м. Київ

DOI: https://doi.org/10.31435/rsglobal_ws/28022020/6928

\section{ARTICLE INFO}

Received: 08 December 2019

Accepted: 14 February 2020

Published: 28 February 2020

\section{KEYWORDS}

battle lesions, secondary pathology, cardiovascular system, prognosis of complications.

\begin{abstract}
Combat activity in eastern Ukraine has shown dramatically different, compared to previous military campaigns, indicators of casualties, which substantiates the need to reform approaches to providing medical assistance to injured combatants. Pathology of internal organs, in particular the cardiovascular system, often accompanies combat trauma, worsens the process of recovery of the injured combatant, leads to his unfitness for military service, sometimes to disability. It is known that in about $20 \%$ of all injured combatants signs of secondary pathology of the cardiovascular system with various manifestations are presented. This percentage even reaches $95 \%$ among the seriously injured, who are treated at the intensive care units. Therefore, an important task for military medicine is the timely identification of high-risk group of patients among injured combatants in order to plan effective prevention measures. In 2018, a method for predicting the risk of developing secondary pathology of the cardiovascular system was developed and tested on the basis of a database of injured combatants from National Military Medical Clinical Center "Main Military Clinical Hospital". We have tested this technique in a specific clinical case of an injured combatant with manifest signs of cardiovascular system abnormalities.
\end{abstract}

Citation: Сидорова Н. М., Пешкова М. І., Воронко А. А., Хоменко І. В., Третяк Д. Д. (2020) Rozrakhunok Ryzyku Rozvytku Sertsevo-Sudynnoi Patolohii, shcho Maie Tryvalyi Perebih, u Postrazhdaloho z Boiovoiu Travmoiu: Klinichnyi Vypadok. World Science. 2(54), Vol.1. doi: 10.31435/rsglobal_ws/28022020/6928

Copyright: () 2020 Сидорова Н. М., Пешкова М. І., Воронко А. А., Хоменко І. В., Третяк Д. Д. This is an open-access article distributed under the terms of the Creative Commons Attribution License (CC BY). The use, distribution or reproduction in other forums is permitted, provided the original author(s) or licensor are credited and that the original publication in this journal is cited, in accordance with accepted academic practice. No use, distribution or reproduction is permitted which does not comply with these terms.

Вступ. Проблема патології внутрішніх органів у постраждалих з травмою, в тому числі 3 бойовою, $є$ актуальною, а вивчення іiі значно активізувалось в період проведення бойових дій на сході України. Досвід, отриманий за цей час, свідчить, що характер ведення бойових дій та отриманих бойових уражень значно змінився порівняно з попередніми воєнними кампаніями, що потребує перегляду підходів до планування медичного забезпечення Збройних Сил України $[1,2]$. 
Особливе місце серед патології внутрішніх органів, яку виявляють у постраждалих 3 бойовою травмою, займає ураження серцево-судинної системи (ССС) [3-5], маніфестація якого може бути представлена як ознаками кардіоміопатії, міокардиту, порушенням систолічної/діастолічної функції лівого шлуночка серця, клапанних структур із розвитком серцевої недостатності, так і розвитком гострого коронарного синдрому, зокрема інфаркту міокарда другого типу із ускладненнями, що можуть складати небезпеку для життя. При цьому початкові ознаки ураження ССС у постраждалого, який отримав бойову травму, можуть бути не виявлені своєчасно.

Лікування постраждалих з бойовими ураженнями проводиться відповідно до протоколів хірургічного лікування та спрямоване, в першу чергу, на ліквідацію наслідків травмування. Тому спостереження за структурно-функціональним станом внутрішніх органів за відсутності вираженої клінічної картини зазвичай обмежується визначенням вітальних даних та базових лабораторних параметрів.

В цих умовах значно підвищується роль лікарів терапевтичного профілю у наданні спеціалізованої медичної допомоги постраждалим з бойовою травмою. Проблема вторинної патології ССС була ретельно вивчена на підставі реєстра постраждалих в Антитерористичній операції/Операції об'єднаних сил у 2014-2018 роках [3, 6-11]. Результатом цих досліджень стала запропонована А. М. Галушкою та Н. М. Сидоровою методика із визначення індивідуального ризику розвитку вторинної патології ССС у постраждалих із бойовою травмою за рутинними показниками крові в перші три доби або на 10-12-ту добу після поранення та запропоновані заходи профілактики цього ускладнення у пацієнтів з високим ризиком [9-11].

Матеріал та методи. Методика визначення ризику розвитку вторинної патології ССС апробована ретроспективно у військовослужбовця, який отримав бойову травму та мав узнаки ураження ССС. Проаналізовані дані обстеження пацієнта в перші 10 діб після поранення та застосована методика розрахунку ризику розвитку вторинної патології ССС. Бойове ураження мало місце в 2015 році, у 2017 році у зв'язку із наслідками важкого поранення військово-лікарською комісією пацієнт був визнаний непридатним до військової служби зі зняттям з військового обліку.

Результати та їх обговорення. Військовослужбовець М., 40 років, під час участі у бойових діях в зоні проведення Антитерористичної операції 27 серпня 2015 року отримав важке мінно-вибухове ураження, яке включало вогнепальне уламкове проникаюче сліпе ураження обох плевральних порожнин із гемопневмотораксом; ураження черевної порожнини 3 пошкодженням кишечника та брижі тонкої кишки; заочеревинного простору із розривом лівого сечоводу, ушкодженням правої нирки, заочеревинною гематомою. Мало місце також ураження хребта та спинного мозку на рівні $\mathrm{L}_{4}-\mathrm{L}_{5}$. Лікування пацієнта було розпочате відповідно до етапів медичної евакуації у військовому мобільному госпіталі, звідки на другу добу він був переведений до Обласної клінічної лікарні ім. Мечникова (м. Дніпро), а на 12 добу у зв'язку 3 важким станом та необхідністю високоспеціалізованого лікування мультидисциплінарною командою був переведений до Національного військово-медичного клінічного центру «Головний військовий клінічний госпіталь» (НВМКЦ «ГВКГ»).

Під час госпіталізації до НВМКЦ «ГВКГ» (7.09.2015): стан хворого важкий, обумовлений бойовим ураженням та анемією внаслідок значної крововтрати.

Індекс маси тіла 28 кг $/ \mathrm{M}^{2}$. Температура тіла $36,8{ }^{\circ} \mathrm{C}$. Рівень артеріального тиску (АТ) 120/80 мм рт. ст. Частота серцевих скорочень (ЧСС) 82 за 1 хв, діяльність серця ритмічна. Частота дихальних рухів 18 за 1 хв.

Шкіряні покриви блідо-рожеві, набряки відсутні.

При огляді та фізикальному обстеженні патології з боку серцево-судинної та дихальної системи не виявляли.

За даними електрокардіограми (ЕКГ) (7.09.2015) синусова тахікардія з ЧСС 98 за 1 хв, зниження вольтажа зубця R в III відведенні, негативний зубець Т до 1 мм у відведеннях V3-V5, депресія сегменту ST до 1 мм у відведеннях V3-V4 (рис.1).

Скарг 3 боку ССС хворий не пред'являв. Зміни на ЕКГ пов'язували 3 анемією середнього ступеню важкості.

Наступного дня в динаміці на ЕКГ спостерігали подальшу незначну негативну динаміку: на тлі регулярного ритму з ЧСС 100 за 1 хв спостерігали зниження вольтажу у стандартних відведеннях, негативний зубець Т біля 1 мм у відведенні V1-V4 (рис. 2). 


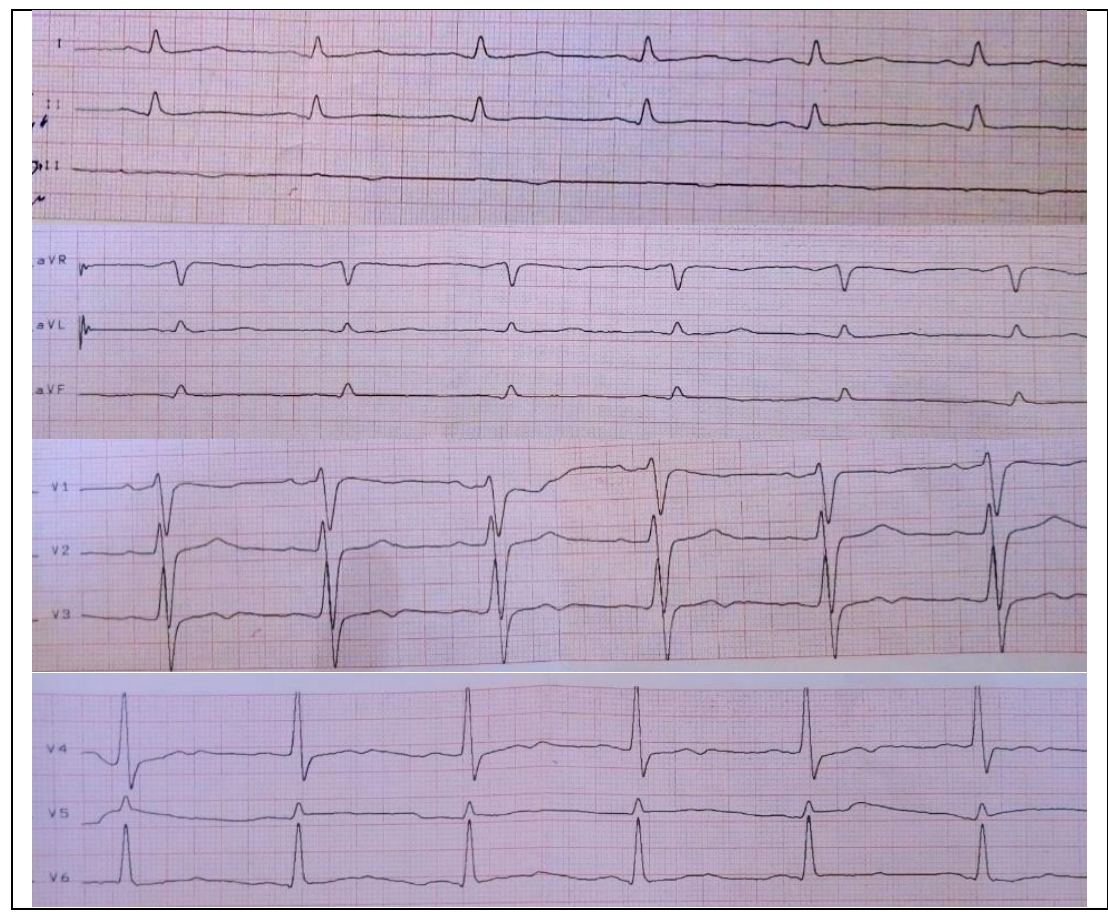

Рис. 1. ЕКГхворого М. 7.09.2015 (швидкість запису 50 мм/год)

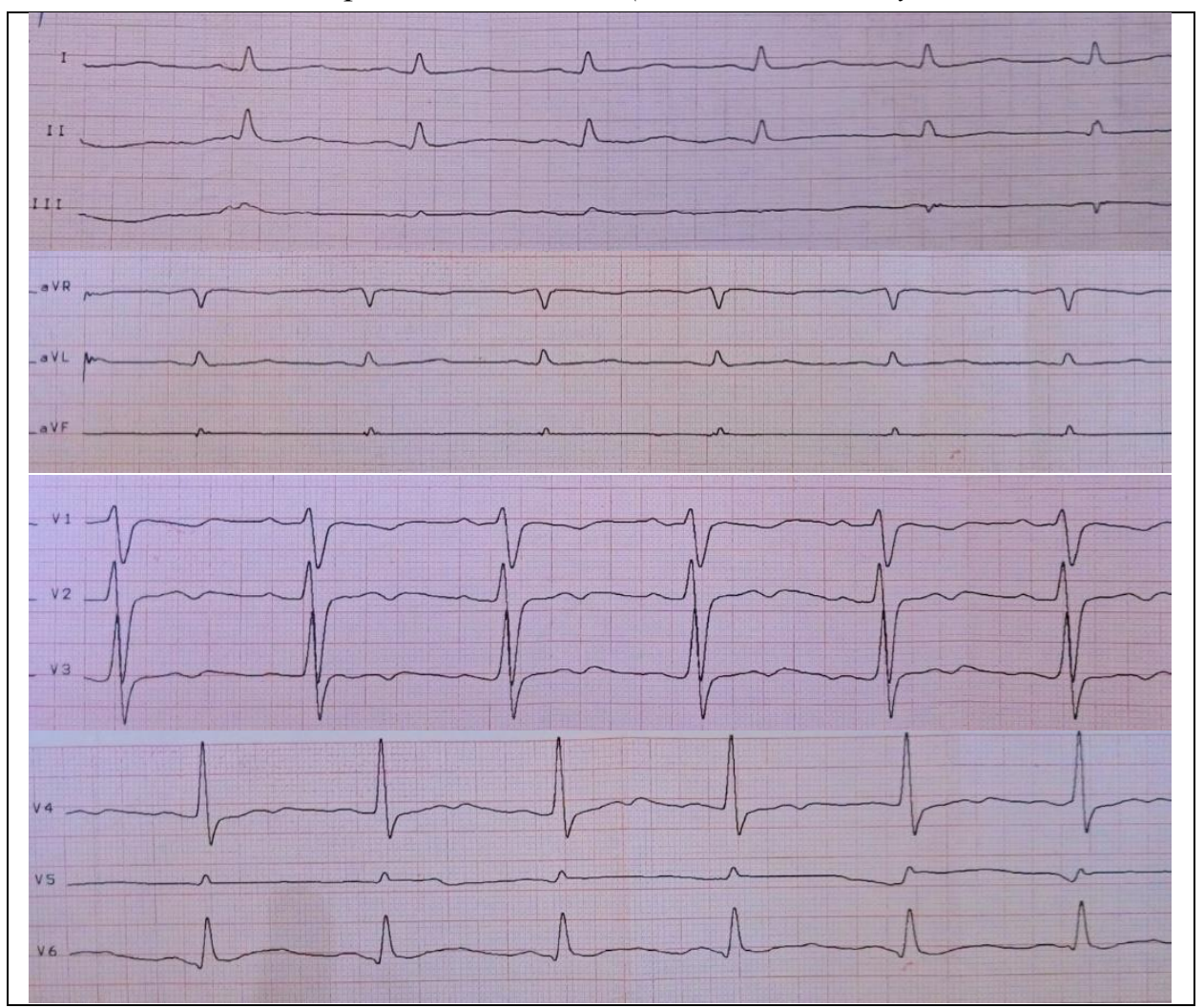

Рис. 2. ЕКГ хворого М. 8.09.2015 (швидкість запису 50 ми/год)

Проводили лікування основної патології - поєднаного складного поранення та анемії. Нормалізація рівня гемоглобіну особливо важлива у хворих із важкими пораненнями особливо при наявності ознак вторинної серцево-судинної патології, що може сприяти зникненню ознак кардіоміопатії [5].

При реєстрації ЕКГ на тлі проведеного лікування 13 вересня виявлена позитивна динаміка: синусова тахікардія відсутня, збільшився вольтаж зубців у стандартних відведеннях, зубці Т у грудних відведеннях позитивні, нормальної амплітуди, депресія ST сегменту відсутня (рис. 3). 


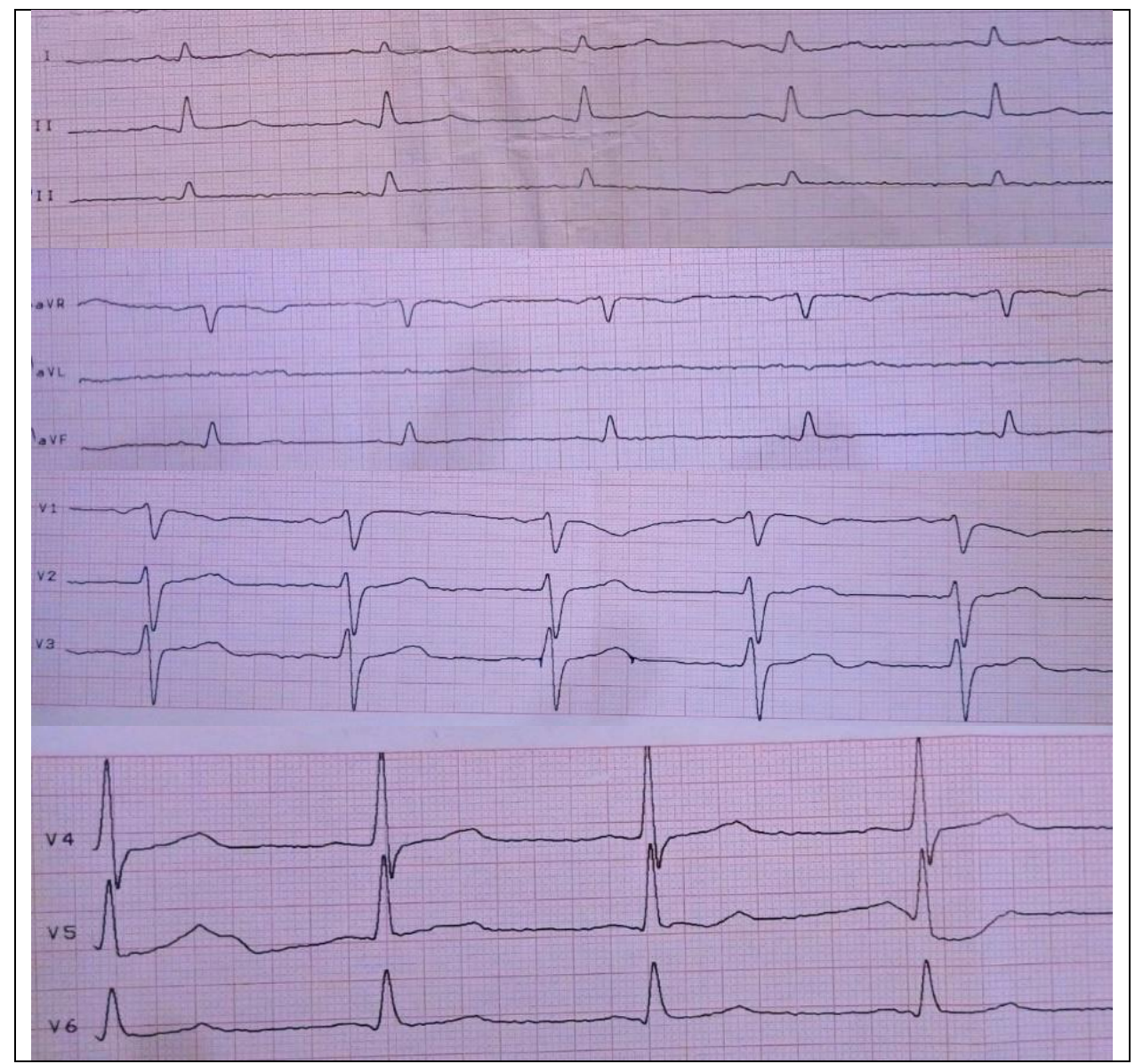

Рис. 3. ЕКГхворого М. 13.09.2015 (швидкість запису 50 мм/год)

Проте подальший контроль ЕКГ виявив, що позитивні зміни не були стабільними. На ЕКГ від 02 жовтня (рис. 4) відмічали депресію сегменту ST до 1 мм у відведеннях V3-V4, a також подовження інтервалу QT, підтверджене розрахунками корегованого до ЧСС показника QT за формулами Bazzett, Friderici, Framingham (табл. 1).

Таблиця 1. Показники ЕКГ хворого М. в динаміці

\begin{tabular}{|l|c|c|c|c|}
\hline \multirow{2}{*}{ Показник } & \multicolumn{4}{|c|}{ Дати } \\
\cline { 2 - 5 } & 07.09 .2015 & 08.09 .2015 & 13.09 .2015 & 02.10 .2015 \\
\hline ЧСС, уд. за 1 хвил. & 98 & 100 & 86 & 78 \\
\hline PQ, с & 0,14 & 0,14 & 0,12 & 0,16 \\
\hline QRS, с & 0,10 & 0,08 & 0,08 & 0,08 \\
\hline QT, с & 0,32 & 0,36 & 0,32 & 0,40 \\
\hline RR, c & 0,62 & 0,60 & 0,70 & 0,76 \\
\hline \multicolumn{5}{|c|}{ Корегований показник інтервалу QT } \\
\hline QTс (Bazzett), мс & 407 & 465 & 380 & 459 \\
\hline QTс (Friderici), мс & 375 & 427 & 360 & 438 \\
\hline QTс (Framingham), мс & 379 & 422 & 366 & 437 \\
\hline Нормальні значення корегованого QT: $320-430$ для чоловіків, 320-450 для жінок \\
\hline
\end{tabular}

Результати ехокардіографічного (ЕхоКГ) дослідження від 30 жовтня свідчили про наявність певних структурно функціональних змін (табл. 2). Аорта незначно розширена на рівні синусів. Порожнини серця в цілому не розширені, передньо-задній розмір правого шлуночка мінімально перевищував верхню межу норми. Регургітація на тристулковому клапані (ТК) I ст., та на мітральному клапані (МК) - мінімальна. Ознаки діастолічної дисфункції лівого шлуночка I типу. Скоротлива здатність міокарда лівого шлуночка не знижена. Виявлені ділянки потовщення листків перикарду з сепарацією в області бокової стінки правого шлуночка 4 мм, в ділянці верхівки 5,4 мм (мінімально перевищує показник норми). 


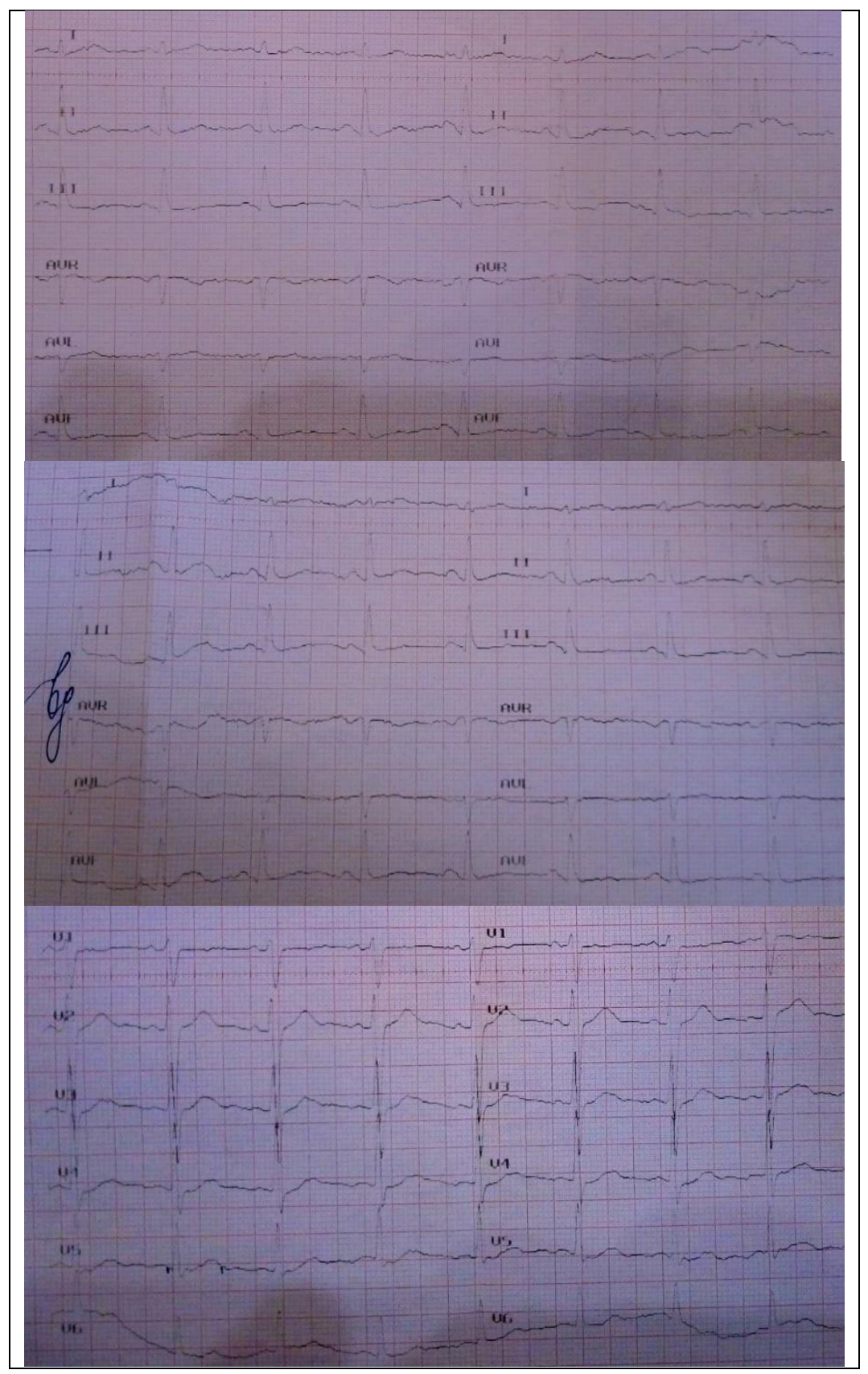

Рис. 4. ЕКГ хворого М. 2.10.2015 (ивидкість запису 25 мм/год)

Таблиця 2. Показники ЕхоКГ хворого М. у динаміці

\begin{tabular}{|l|c|c|c|}
\hline \multirow{2}{*}{ Показник } & \multicolumn{3}{|c|}{ Дата } \\
\cline { 2 - 4 } & 30.10 .2015 & 16.11 .2015 & 05.04 .2017 \\
\hline АО, см & 2 & 3 & 4 \\
\hline ЛП, см & $2,3-4,0-3,6$ & $3,8-3,56$ & $3,8-3,5$ \\
\hline КДО, мл & 3,2 & 3,3 & 3,35 \\
\hline КСО, мл & 142 & 122 & 124 \\
\hline $\begin{array}{l}\text { Фракція викиду } \\
\text { ЛШ, \% }\end{array}$ & 55 & 47 & 50 \\
\hline ТМШП, см & 61 & 62 & 59 \\
\hline ТЗСЛШ, см & 0,96 & 1,04 & 0,10 \\
\hline$\Delta$ рАК, мм.рт.ст & 0,81 & 1,03 & - \\
\hline$\Delta$ рКЛА, мм.рт.ст & 5,3 & 4,5 & - \\
\hline
\end{tabular}


Продовження таблиці 2.

\begin{tabular}{|l|c|c|c|}
\hline \multicolumn{1}{|c|}{1} & 2 & 3 & 4 \\
\hline$\Delta$ рМК, мм.рт.ст & - & 3 & - \\
\hline СДЛА, мм.рт.ст & 19 & 26 & 21 \\
\hline ПЗР ПШ, см & 2,82 & 2,62 & 2,56 \\
\hline Відкриття АК, см & 2,2 & 2,0 & - \\
\hline АО & &
\end{tabular}

АО - аорта, ЛП - ліве передсердя, КДО - кінцевий діастолічний об'єм, КСО - кінцевий систолічний об’єм, ТМШП - товщина міжшлуночкової перетинки, ТЗСЛШ - товщина задньої стінки лівого шлуночка, АК - аортальний клапан, КЛА - клапан легеневої артерії, МК мітральний клапан, СДЛА - систолічний тиск в легеневій артерії, ПЗР - передньо-задній розмір, ПШ -правий шлуночок серця, ЛШ - лівий шлуночок серця

За даними ЕхоКГ, проведеного в динаміці через 2 тижні, відмічали появу пролапсу стулок ТК з регургітацією до II ст, пролапсу передньої стулки МК з регургітацією I ст. Порожнини серця були не розширені, ознак діастолічної дисфункції не виявляли, збереженою залишалась глобальна скоротлива здатність міокарда лівого шлуночка, але 3 ознаками дискінезу МШП. Зберігалась мінімальна сепарація листків перикарду (до 5,2 мм).

На підставі виявлених змін хворому було встановлено діагноз: гострий інфекційний міоперикардит 3 наявністю незначної кількості вільної рідини в порожнині перикарду. Вторинний пролапс стулок трикуспідального клапану з регургітацією I-II ступеню, передньої стулки мітрального клапану з регургітацією до I ступеню. СН 0.

При контрольному огляді через 2 роки спостерігали збереження певних порушень на ЕКГ та за даними ЕхоКГ.

Так, при контрольній реєстрації ЕКГ 09 березня 2017 року: синусовий ритм, ЧСС 62 за 1 хв, електрична вісь серця не відхилена. Знижений вольтаж комплексу QRS в I та aVL відведеннях, перехідна зона зміщена до V5. Тривалість інтервалу QT $=0,38$ с, його корегований показник не перевищував норму та складав за формулою Bazett 388 мс, за формулою Friderici 385 мс, за формулою Framingham 386 мс (рис. 5).

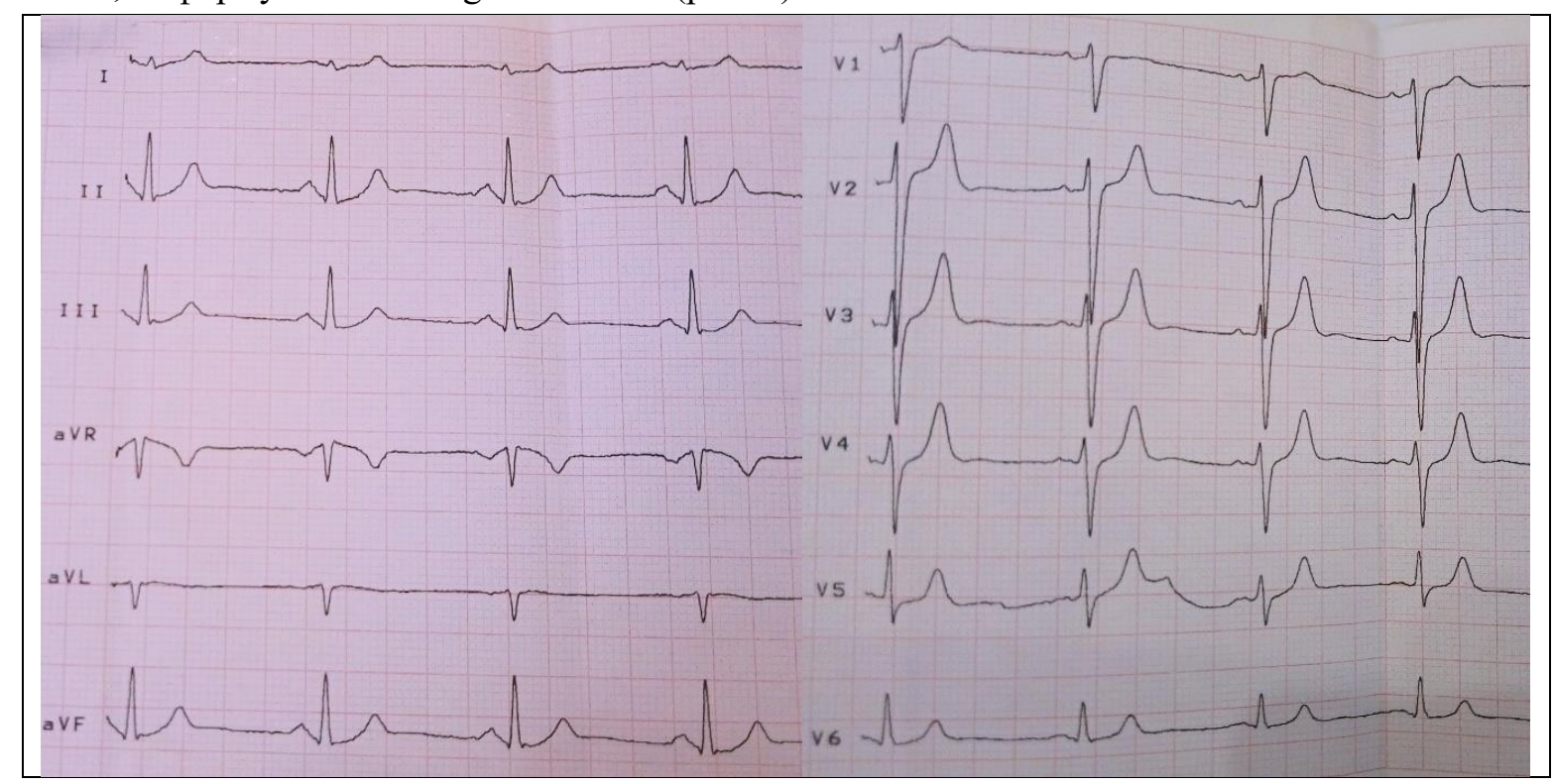

Рис. 5. ЕКГхворого М. 09.03.2017 (швидкість запису 50 мм/год)

За даними ЕхоКГ в цей період (05.04.2017) виявляли ознаки пролапсу передньої стулки МК $з$ регургітацією I ст., пролапсу септальної стулки ТК з регургітацією I ст, зберігалась діастолічна дисфункція лівого шлуночка І-го типу без порушень скоротливої функції міокарду лівого шлуночка. Виявляли вогнища ущільнення листків перикарду.

Таким чином, зміни на ЕКГ та ЕхоКГ свідчили про наявність у хворого кардіоміопатії 3 залишковими ознаками через 2 роки після травми. В даному випадку поява ЕКГ, а згодом i ЕхоКГ, змін, що були виявлені у 2015 році та швидка їх динаміка у гострому періоді дозволяє пов'язати розвиток кардіальної патології з бойовою травмою. 
Раніше в роботах співробітників Української військово-медичної академії [9-11] було запропоновано методику розрахунку ризику розвитку серцево-судинної патології у пораненого 3 бойовою травмою за формулами, що враховують лабораторні показники, визначені на 1-3-ту та на 10-14-ту добу від отримання травми відповідно [9]:

$\mathrm{P}_{1-3}=0,71-0,013 \times 3 Б+0,099 x \Gamma$, де $\mathrm{P}$ - загальний ризик, ЗБ - загальний білок, Г/л, Г глюкоза, ммоль/л;

$\mathrm{P}_{10-14}=0,610-0,009 \times 35+0,085 \times \Gamma$

Показник більше 0,5 означає високий ризик розвитку вторинної патології ССС. За інформацією авторів методики, кращі оперативні характеристики має модель розрахунку за показниками 1-3-ої доби після поранення. Для розрахунку ризику розвитку вторинної патології ССС у хворого М. ми застосовували модель для показника 10-14-ої доби, оскільки тільки ці дані були наявні в медичній документації пацієнта.

Згідно даних ретроспективного аналізу, на 10-14 добу пацієнт мав наступні дані. В загальному аналізі крові (6.09.2015): гемоглобін 89 г/л; гематокрит 0,27 г/л; еритроцити $3,11 \times 10^{\times 12} /$ л; лейкоцити $8,9 \times 10^{x} 9 /$; тромбоцити 176 г/л. В біохімічному аналізі крові (6.09.2015): натрій 139 ммоль/л; калій 4 ммоль/л; кальцій 1,2 ммоль/л; глюкоза 5,2 ммоль/л; загальний білок 58 г/л; альбумін 33 г/л; білірубін 11 мкмоль/л; аланінова трансаміназа 30 Од/л; аспарагінова трансаміназа 32 Од/л; креатинін 103 мкмоль/л.

В цей час зміни на ЕКГ були відсутні: ритм синусовий, регулярний, вертикальне положення електричної вісі серця. Ознак погіршення кровопостачання міокарду лівого шлуночка серця не спостерігали.

Тобто, відповідно до наявних даних медичної документації станом на 6.09.2015 глюкоза крові пацієнта склала 5,2 ммоль/л, загальний білок - 58 г/л. Таким чином, показник $\mathrm{P}_{10-14}$ склав 0,53, що відповідає високому ризикові.

За запропонованою авторами методикою можна вирахувати індивідуальний ризик хворого за формулою:

$\mathrm{Pi}=1 /\left(1+\mathrm{e}^{-\mathrm{P} 10-14}\right)$, де $\mathrm{e}-$ основа натурального логарифму $(2,71828182846)$

При обрахунку за запропонованою формулою, показник індивідуального ризику хворого М. визначений на рівні $63 \%$.

Таким чином, ми підтвердили ефективність запропонованої методики розрахунку ризику розвитку вторинної патології ССС у постраждалого з бойовою травмою на прикладі конкретного клінічного випадку. Ризик розвитку вторинної патології ССС у хворого М. можна було розрахувати та прогнозувати в перші 14 діб після поранення, в той час як реально верифікація ознак кардіоміопатії із ураженням міокарду, перикарду та клапанних структур зайняла багато часу та базувалась на періодичних оглядах спеціалістів терапевтичного профілю. Згідно запропонованої функціонально-організаційної моделі надання медичної допомоги терапевтичного профілю військовослужбовцям з бойовим ураженням та алгоритму первинної та вторинної профілактики вторинної серцево-судинної патології у постраждалих з бойовою травмою [12], у всіх постраждалих доцільно визначати індивідуальний ризик розвитку вторинної патології ССС на 1-3-тю або 10-14-ту добу. Пацієнти групи високого ризику розвитку цього ускладнення, відповідно до запропонованого алгоритму мають знаходитись під наглядом лікаря-терапевта, отримувати відповідну терапевтичну медичну допомогу, що включає заходи первинної та вторинної профілактики, метаболічну підтримку залежно від виявлених порушень ліпідного/ білкового/вуглеводного обмінів.

В даному випадку вторинна патологія ССС, яку можливо було прогнозувати в перші два тижні від поранення, супроводжувалась змінами на ЕКГ та структурно-функціональними порушеннями серця за даними ЕхоКГ, що потребувало диференціальної діагностики між міокардитом та гострим коронарним синдромом метаболічного генезу. Даний випадок продемонстрував також багатогранність кардіальних проявів такого ускладнення бойової травми. У постраждалого М., крім описаних раніше Н. М. Сидоровою [3] симптомів та синдромів, виявили пролонгацію інтервалу QT, яка часто залишається нерозпізнаною внаслідок відсутності розрахунку корегованого показника QT при рутинному аналізі ЕКГ, зокрема при наданні медичної допомоги хірургічного профілю. Факт пролонгації інтервалу QT може маскуватись фізіологічною в умовах травматичної хвороби тахікардією як ознакою симпатикотонії. Проте слід мати на увазі, що минуща пролонгація інтервалу QT може бути пов'язана із супутнім лікуванням пацієнтів (значна кількість антибактеріальних та інших засобів здатна подовжувати інтервал QT) [13, 14]. 
Ця виявлена нами під час аналізу представленого клінічного випадку особливість обгрунтовує важливість ретельного підходу до аналізу ЕКГ, в тому числі обов'язкового розрахунку корегованого показника інтервалу QT у пацієнтів, які проходять лікування 3 приводу бойової травми. Слід також звернути увагу на медикаментозні засоби, що здатні впливати на тривалість інтервалу QT у цієї категорії хворих, оскільки подовження інтервалу QT пов'язано із несприятливим кардіальним прогнозом. За нашою думкою, при розрахунках показника інтервалу QT краще використовувати формули Friderici, Framingham, оскільки їх показники співпадають, в той час як використання формули Bazzett рекомендоване для ЧСС в діапазоні 60-90 за 1 хв [14]. За цією формулою показники корегованого інтервалу QT були значно вищі, що може призвести до переоцінки ступеню пролонгації інтервалу QT.

Висновки. 1. Апробована в наведеному клінічному випадку методика визначення осіб, які отримали бойову травму та мають підвищений ризик розвитку вторинної патології $\mathrm{CCC}, \epsilon$ ефективною та зручною, дозволяє визначити індивідуальний ризик пацієнта щодо зазначеного ускладнення вже на 1-3-ту або 10-14-ту добу після поранення.

2. Згідно $з$ даними Н. М. Сидорової та співав. [12] та наведеним клінічним випадком необхідне спостереження за пораненими не тільки лікарями хірургічного, але й терапевтичного профілю з метою своєчасної діагностики кардіоміопатії.

3. Даний клінічний випадок демонструє необхідність ретельного обстеження постраждалих, які перенесли бойову травму, з метою раннього виявлення патології ССС, яка може мати різні прояви.

\section{REFERENCES}

1. Булах О.Ю. Дослідження санітарних втрат Збройних сил України та напрямків оптимізації медичного забезпечення в ході антитерористичної операції/ О.Ю.Булах, В.І. Стриженко //Сучасні аспекти військової медицини: збірник наукових праць Головного військово-медичного клінічного центру «ГВКГ» МО України. - Вип. 22. Частина І. - К., 2015. - С.15-25.

2. Внутренние болезни. Военно-полевая терапия: Учебное пособие. / Под ред. А. Л. Ракова и А. Е. Сосюкина. - СПб.: ООО «Издательство ФОЛИАНТ», 2003. - 384 с.

3. Сидорова Н. М. Вторинна патологія серцево-судинної системи у військовослужбовців з бойовою травмою - сучасний погляд на проблему/ Н. М. Сидорова /Військова медицина України. - 2018. - №1. - С. 43-53.

4. Пилипюк В.А. Бойова терапевтична патологія. Захворювання серцево-судинної системи/ В.А. Пилипюк// Сучасні аспекти військової медицини: збірник наукових праць Головного військовомедичного клінічного центру «ГВКГ» МО України. - Вип. 21. - К., 2014. - С.263-266.

5. Голод А. Г. Патологічні зміни серцево-судинної системи у важкопоранених // Cучасні аспекти військової медицини. 2015. Вип. 22. Ч.1. С.166-168.

6. Казмирчук А.П., Мясников Г.В., Сидорова Л.Л., Сидорова Н.Н. Предварительные результаты ретроспективного анализа историй болезни пострадавших в зоне проведения антитеррористической операции // Сучасні аспекти військової медицини. 2015. Вип. 22, Ч. 1. - С. 39-44.

7. Казмірчук А.П., Дрюк М.О., Денисенко І.Г., Циц О.В. Організація надання спеціалізованих видів медичної допомоги пораненим. Травмованим та хворим учасникам АТO // Сучасні аспекти військової медицини. 2016. Вип. 23. С.34-44.

8. Казмірчук А.П., Мясников Г.В., Сидорова Н.Н., Сидорова Л.Л. Патология внутренних органов при боевой травме. Реестр пострадавших в зоне проведения антитеррористической операции // Сучасні аспекти військової медицини. 2014. Вип. 21. С.44-49.

9. Halushka A., Kazmirchuk A., Sydorova N., Chaikovsky I. Cardiovascular pathology in combatants. Toliman, Brookline, 2018. - P. 6-60.

10. Sydorova N, Halushka A. Math modeling of clinical processes for improvement of military therapeutcal assistance organization for combatants with battle trauma// World Science. 2018. № 6(34). Vol.5. P. 29-33.

11. Галушка А.М., Сидорова Н. М. Математична модель моделювання ризику розвитку вторинної патології серцево-судинної системи у постраждалих з бойовою травмою // Військова медицина України. 2018. №1. С. 19-28.

12. Сидорова Н. М., Галушка А. М., Воронко А. А., Казмірчук А. П., Третяк Д. Д., Спаська Г. О., І. В. Хоменко, Науменко М. В. Сучасні воєнні конфлікти та вторинна патологія серцево-судинної системи: статистика, можливості прогнозування та попередження// Сучасні аспекти військовоі медицини. 2019. Вип. 26. Ч. 2. С. 70-79.

13. Combined list of drugs that prolong QT and/or cause torsades de pointes (tdp) https://crediblemeds.org/pdftemp/pdf/CombinedList.pdf

14. Burns E. QT Interval. 2019 https://litfl.com/qt-interval-ecg-library 